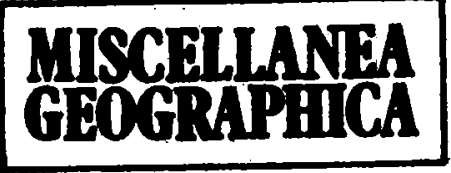

WARSZA WA 1990

\title{
Andrzej Lisowski
}

WIND HAZARD IN RURAL POLAND (1975-1986)

The human environment provides various phenomena and processes which tend to delimit the fulfillment of human needs. Among them are the so-called natural disasters, i.e. extreme states of environmental components which exceed the average human anticipation and result in considerable material and social losses which can be eliminated only by external aid (I. Burton et al. 1978).

Underestimation of social consequences of these phenomena in public opinion is related, to great extent, to the incidental character of the occurrence of the extreme conditions of environmental components and to relatively high costs of preventive measures (Petak 1985, Lisowski 1989).

One of the most acute geophysical environmental hazards worldwide are wind hazards ${ }^{1}$ related to high velocity of air masses movement with respect to the surface of the Earth. The mean daily wind velocity per year in Poland does not exceed $4 \mathrm{~m} / \mathrm{s}$ (in winter and autumn it reaches its highest level). In Poland winds of a $10 \mathrm{~m} / \mathrm{s}$ or more velocity are considered to be severe or very severe (Atlas Klimatyczny Polski, 1971). However, these winds constitute only $4-5 \%$ in the register of yearly wind velocity in the country, except for the Baltic coast and small regions along the eastern border and the highest mountain ranges (Tatra, Karkonosze).

As regards their physical characteristics, winds in Poland cannot be compared to tropical ones, yet potential damage results not only from the extreme conditions of the natural environment but - to a great

1 At the turn of the 21st century in the US wind hazards (such as tornadoes, hurricanes, squalls and others) will most probably be a major cause of life hazard $(60 \%$ of all casualties) and of material losses $(50 \%)$ among all other kinds of geophysical hazards. Presently squalls alone (excluding tornadoes and hurricanes) are responsible for 5 casualties per year, 851 homeless, 373 lobless. (Petak, Atkisson, 1982). 
extent - from vulnerability of a community in face of certain hazards (i.e. badly built buildings). In colloquial Polish and also in insurance vocabulary all severe winds are called "hurricanes". According to PZU (State Insurance Company) regulations, "hurrican damage" is a largescale damage caused by winds whose min. velocity is $24.5 \mathrm{~m} / \mathrm{s}$ i.e. $10^{\circ}$ on the Beaufort scale. A single damage may be considered to be "hurricane damage" if there is an evidence of hurricane activity in the immediate neighbourhood or if the kind and dimension of the damage are an obvious evidence of wind acitivity of $24 \mathrm{~m} / \mathrm{s}$ or more velocity (M. Brzostek 1977). Such a high threshold seems to be controversial even in PZU circles. Winds of $\max$ velocity of over $15 \mathrm{~m} / \mathrm{s}$ occur practically in the entire country (D. Piasecki 1952). However, winds of max. velocity of over $30 \mathrm{~m} / \mathrm{s}$ are considerably more rare; they were more frequent in the 80s than in the 70s (D. Kuziemska 1988).

Damage caused by severe winds in Poland is, as a rule, minor (compensation for serious building damage does not usually exceed $1 / 3$ of the original value of the building).

However, this damage tends to occur on a massive scale and causes serious trouble to the victims. Sporadically there occurred casualties especially in 1960, 1962 and 1984. Yet the compensation paid by PZU is relatively high. For instance, in 1986 it was comparable to the compensation paid for car theft $(2,8$ billion zlotys and 1 billion zlotys, respectively).

The subject of the present paper is the damage caused by severe winds in Poland in 1975-86. The unpublished data used for the purposes of this paper refer to the losses suffered by individual farmers and farming co-operatives. Since 1958 individual farmers have been required to pay a natural disaster insurance for buildings, movables crops and livestock. Therefore, the damage discussed here relates to rural regions where the losses are 10 times higher than in towns (weaker buildings, scattered layout).

Severe winds cause the most serious damage in villages with scattered buildings, located on the open plain. Over $2 / 3$ of the damage occurs in farm buildings which usually have weak structures. Contrary to the USA, in Poland the damage of movables caused by severe winds is fairly low (Poland 7,1\%, USA 28,3\%).

However, in Poland, just as in the US, material losses caused by strong winds - as compared with other natural disasters - have been increasing over the years. Thus, for instance, in 1951-74 the highest compensation involved fire in farm houses and buildings $-75 \%$, while in 1975-86 the percentage dropped to $66,5 \%$; on the other hand, there was an increase in the compensation paid for wind $(28,9 \%)$ and flood 
damage $(3,7 \%)$. The lowest sum for severe wind damage was paid in $1951-60$ and $1975-79$ (less than $20 \%$ of the total compensation for all hazards). As regards movables, the greatest hazard for rural communities are: fire (over 90\% of compensation) and floods (6\%). However, lack of responsibility and technological failure (electric equipment and installations) are still the basic sources of rural hazard. Also the greatest number of fire casualties gives priority to fire prevention.

The relative intensity of damage (the amount of compensation in relation to the number of insured farms) caused by severe winds in Poland has increased in 1981-86. The degree of damage done to buildings in $1981-86$ was on the average $45 \%$ higher than in $1975-80$ and in the case of movables $50 \%$ higher $^{2}$. In the period covered by the present paper winds caused least damage in 1976-79, the average yearly intensity of damage to bhildings being $1.8 \%$ and to movables - $0,075 \%$.

Three factors were taken into consideration in order to identify the regions suffering most from wind hazards:

1. the degree of damage (the amount of compensation paid in relation to the total number of insured farms),

2. participation of the region in the value of compenasation paid nationwide,

3. the amount of PZU refusals of insurance claims (the amount of refusals in relation to the total number of claims).

In each case the figures represent the arithmetic mean from 1975-86. Due to considerable differences in the degree of damage and the value of compensation paid, the damage done to buildings and movables is treated separately.

The regional distribution of damage caused by severe winds is more regular in case of buildings (Fig. 1A, B) than in the case of movables. Spatial variation of the degree of damage and the value of compensation paid is almost twice as high for movables (since the damage occurs more sporadically) than for buildings (coefficient of variation i.e. the ratio of standard deviation and arithmetic mean for movable is $94 \%$ and $122 \%$ repectively, and for buildings $-46 \%$ and $54 \%$ respectively). The amount of PZU refusals of insurance clains shows the least spatial differentiation (coefficient of variation 14\% for buildings, $36 \%$ for movables).

The maps (Fig. 2A, B) show the relative intensity of severe wind hazards to buildings (A) and movables (B) in individual farms in Po-

2 In the USA it is expected that in 1970-2000 damage caused by severe winds (excluding hurricanes and tornadoes) will increase by $197 \%$ and the damage caused by all wind hazards by 222\% (Petak, Atkisson 1982). 


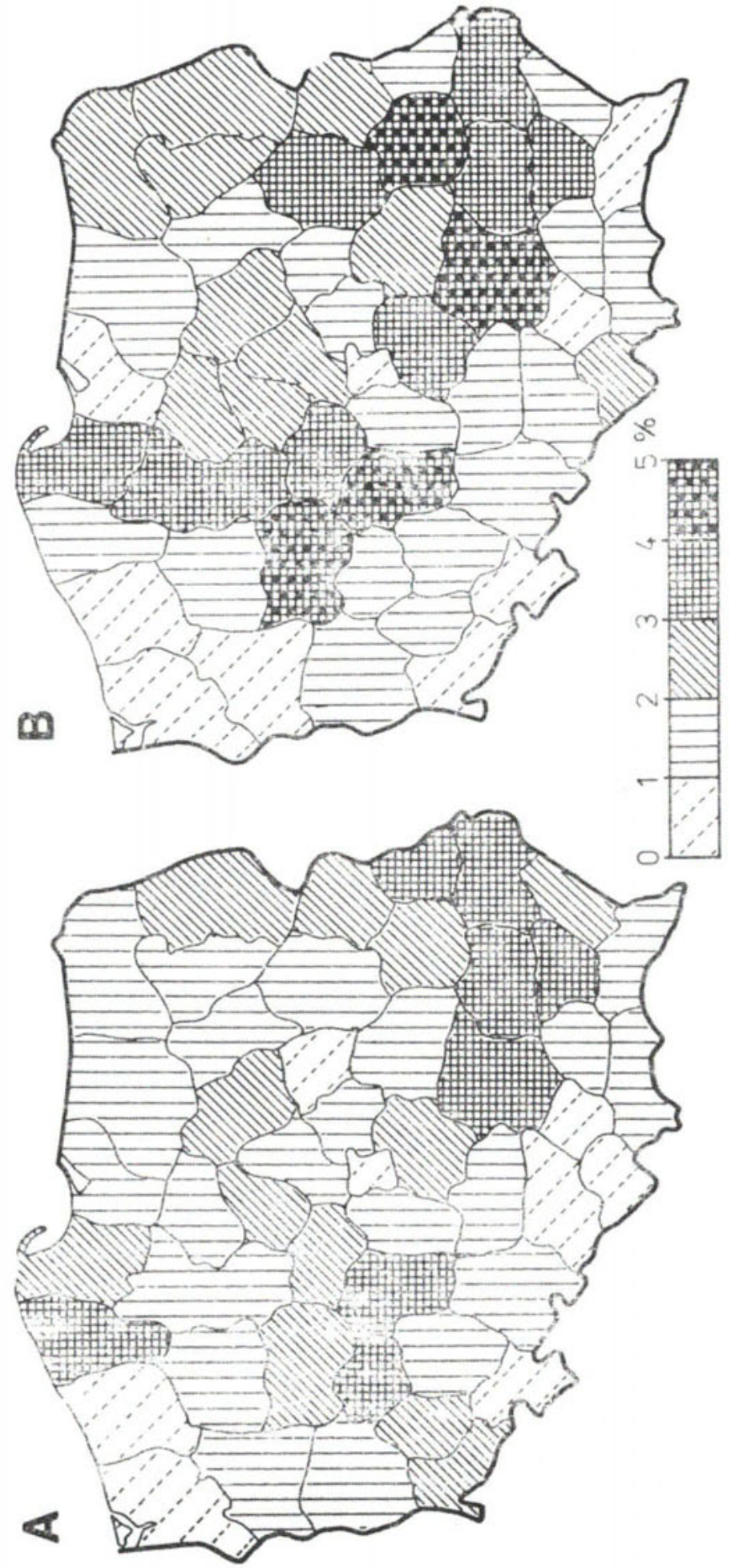

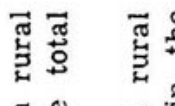

듣․.

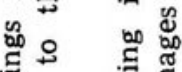

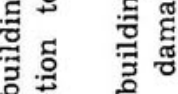

巨苑

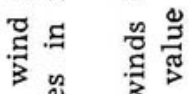

政密

岕焉芯

हू प्य

出范

洁

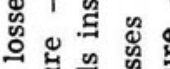

4艹

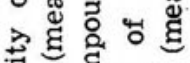

ญ

⿷匚

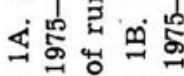

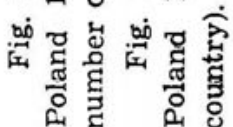




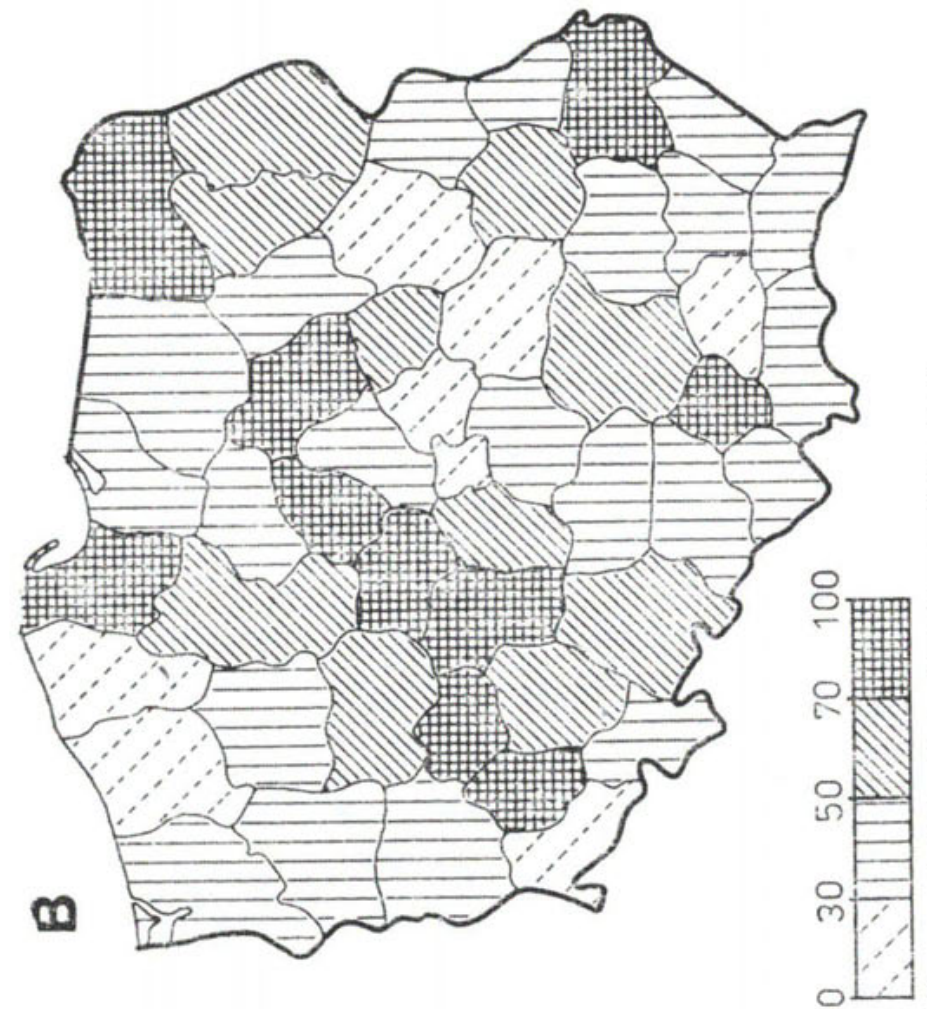

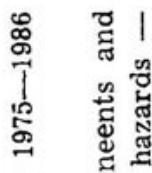

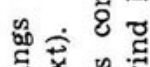

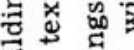

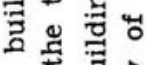

ఏ ڤ

ชี 1 ช

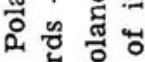

- ก็

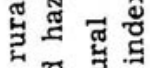

운

弯

융 㟧

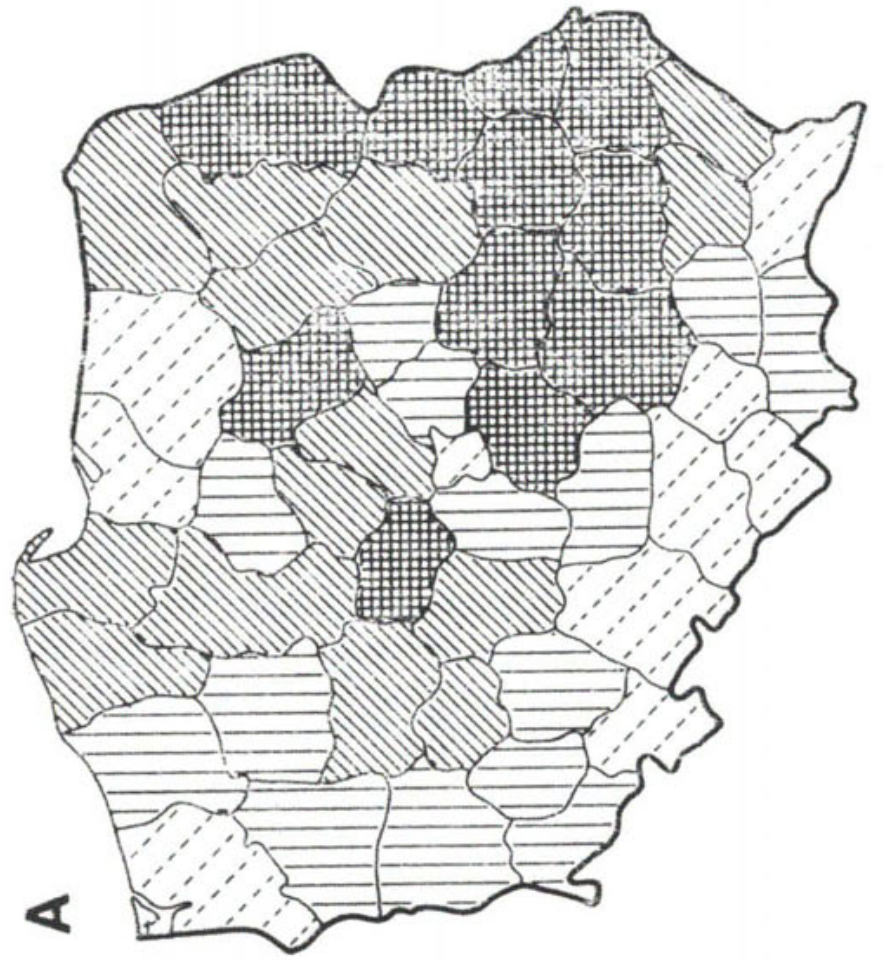

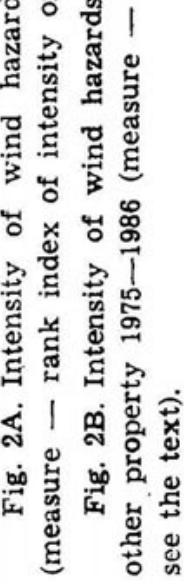


land in $1975--86$ on a scale of 0 to 100 . The ranking index proposed by M. Ciechocińska (1975) for the determination of a standard of living has been used here for identifying most hazardous areas. The formula is:

$$
I=100-100 \frac{R-N}{N(C-1)}
$$

where:

$I$ - degree of hazard index $(0 \leqslant \mathrm{I} \leqslant 100)$,

$R$ - sum of ranks of regional units according to the value of the three features (variables)

$N$ - number of features (variables) taken into consideration

$\mathrm{C}$ - number of regional units

Regions suffering the most serious wind hazards in the analysed period are located mainly in the eastern and mid-western part of the country $(50 \leqslant I \leqslant 90)$. The least hazardous were the southern and western voivodships as well as the highly urbanized voivodships (Katowice, Łódź and metropolitan Warsaw). In the eastern and mid-western regions buildings were most susceptible to damage, while in the mid-western and south-eastern regions - the movables were. The high degree of damage done to buildings in the eastern part of the country was due - most probably - to the lesser resistance of the buildings to severe wind activity (a higher share of the wooden farm buildings and thatched roofs). Hence, in this part of the country there is the greatest number of refusals of insurance claims (on the average $40 \%$ in Radom, Ciechanów, Chełm, Białystok voivodships) although the total number of damages paid is also relatively high.

The actual wind hazard involve the eastern and mid-western voivodships (along the latitudinal line) including Gdańsk voivodship. These regions are highly populated and play an important role in national agriculture (hazards are lower in underpopulated rural areas and villages with a scattered layout). The mideastern and eastern rural voivodships have at the same time the lowest standard of living (the quality of buildings, a lack of full infrastructure).

The resulting view of regional differentiation of wind hazards is, in fact, a resultant of the intensity of occurrence of high velocity winds and susceptibility of certain regions to the potential wind damage. The synoptic, stations network does not register all the cases of the occurrence of severe and very severe winds. A severe wind may continue for several days, but it may as well last a few minutes causing considerable damage to a very limited area. The evidence of the occurrence of such a severe wind may be found only upon an inspection of the site'(i.e. 
summer time wind whirls) since effects of such a phenomenon cannot always be confirmed by meteorological observation.

On the other hand, the register of damages caused by severe winds in rural areas is not always unequivocal. It undoubtedly contains a "human factor" since it is a resultant of the victims' perception and doubts of insurance inspectors. The loss assessment is, as a rule, more objective in the case of disasters affecting buildings than in those affecting the movab'es. However, even ii case of buildings the loss assessment becomes controversial when it concerns old and delapidated ones. Certain confusion may also occur due to changes in insurance regulations (M. Brzostek 1977).

In 1975-86 PZU refused to pay claims for 27,4\% of damaged buildings and 22,7 of damaged movables. In 1975-86 the number of refusals was adversely proportional to the number of claims paid nationwide for building damage $\left(r_{s}=-0,8\right)$; however, this ratio has not been noticed in the case of movables. The majority of claim refusals for building damage notionwide occurred in 1979 (51\%) and for the damage of movables in $1977(36 \%)$. It should also be stressed, that in these years considerable damage to buildings and movables due to flood was noted.

The regions most exposed to wind hazards (considerably high degree of losses, high value of compensation paid, large number of refusals) are: Zamość and Lublin voivodships - buildings; Konin, Włocławek, Kraków, Ciechanów voivodships - movables (Fig. 2 A, B).

There has been regional variability in the occurrence of wind hazards over the period between 1951 and 1986. (In 1975 the country was divided into new administrative units). In 1951-57 the greatest intensity of losses (the amount of compensation paid) occurred on the entire northern stretch along the Baltic coastline (at this time the wind hazard insurance was optional for farmers). In 1958-74 the greatest damage caused by severe winds occurred in the north-west, south-east and north-east (M. Brzostek 1977), while in 1975-86 it occurred along the latitudinal line in mid-western and eastern parts of the country.

\section{REFERENCES}

Atlas Klimatyczny Polski (The Atlas of the Polish Climate), 1971, Wyd. Komunikacji i Łączności, Warszawa.

Brzostek M., 1977, Kierunki rozwoju ubezpieczeń budynków od huraganu $w$ Polsce (Trends in the development of hurricane insurance of buildings in Poland), Wiadomosci Ubezpieczeniowe, No. 1, pp. 1-7.

Burton I., R. W. Kates, G. White, 1978, The Environment as Hazard, Oxford University Press, New York. 
Ciechocińska M., 1975, „Dynamika zmian w przestrzennym zróżnicowaniu warunków bytu ludności w latach 1960-70" (The dynamic changes in the regional differentiation of the standard of living in 1960-70), Biuletyn KPZK $P A N$, No. 87, pp. $185-224$.

Kuziemska D., 1988, Krótkotrwate, groźne zjawiska atmosferyczne w Polsce $w$ latach 1951-1987 (Short-term grave atmospheric phenomena in Poland in 1951-1987), IMGW, Warszawa (typescript).

Lis owski A., 1990, "Social effects of natural hazards in social policy of the state in Poland", in: S. Otok (ed.) The Environment in Social Policy of the State.

Petak W.A., A. A. A. A $\mathrm{tk}$ is $\mathrm{s}$ on, 1982, Natural Hazard Risk Assessement and Public Policy. Anticipating the Unexpected, Springer Verlag, New York.

Petak W. A., 1985, "Emergency Management. A Challenge for Public Administration", Public Adm. Rev. 45, pp. 3-6.

Pi a secki D., 1952, „Wiatry o maksymalnych prędkościach na obszarze Polski w latach 1928-38", (Winds of max. velocity in Poland in 1928-38), Wiadomosci Stużby Hydrologicznej $i$ Meteorologicznej, vol. III, secion 2a, PIHM, Warszawa. 